Physical Therapy Journal of Indonesia (PTJI) 2021, Volume 2, Number 2: 30-35

E-ISSN : 2722-6034; P-ISSN : 2722-0125

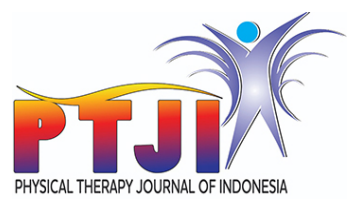

\title{
The Correlation of Body Mass Index and Physical Activity on Cardiorespiratory Endurance among Elderly
}

\author{
I Kadek Dwi Widhi Dharma, ${ }^{1 *}$ I Putu Prisa Jaya, ${ }^{1}$ I Made Dhita Prianthara ${ }^{1}$
}

\begin{abstract}
Background: Elderly is assumed as a person who has been at the age of 60 and will be some alterations, physical alteration in term ages. The physical alteration that is commonly found in the elderly is a condition of the body mass index that will not be taken care of optimally due to the degenerative factor.

Purpose: This study is aimed at proving the relation of body mass index towards the cardiorespiratory endurance along with the relation of physical activities towards the cardiorespiratory endurance.

Methods: The study design was cross sectional with the population of the elderly in Banjar Alas Arum in which they qualified the inclusion and exclusion criteria. From the elderly that had been

samples. The BMI was measured by formula calculation. The physical activity level was measured by the International Physical Activity Questionnaire and the cardiorespiratory endurance used 6 minutes walking test. The data were analyzed by software computer which was Somers' D test.

Results: The result of this study showed that by 48 the relation of BMI towards the cardiorespiratory endurance showed that the result of $p$ was $0.000(p<0.05)$. Concerning on the relation of physical activities towards the cardiorespiratory endurance shown that the result of $p$ was $0.000(p<0.05)$.

Conclusion: It can be concluded that there is a significant relation in this study.
\end{abstract} selected by means of purposive sampling, it was obtained 48
'Study Program of Physical Therapy, College of Health Sciences, Universitas Bali Internasional, Bali, Indonesia

*Corresponding to: I Kadek Dwi Widhi Dharma, Study Program of Physical Therapy, College of Health Sciences, Universitas Bali Internasional, Bali, Indonesia;

widhidharma9@gmail.com

Received : 2021-08-03 Accepted : 2021-11-01

Published : 2021-12-02

Keywords: body mass index, cardiorespiratory endurance, elderly, physical activity

Cite this Article: Dharma, I.K.D.W., Jaya, I.P.P., Prianthara, I.M.D. 2021. The Correlation of Body Mass Index and Physical Activity on Cardiorespiratory Endurance among Elderly. Physical Therapy Journal of Indonesia 2(2): 30-35. D0l: 10.51559/ptii.v2i2.30

\section{BACKGROUND}

Elderly is the final stage in human life. Aging or getting old is a condition that occurs in human life. Getting old is a natural process and not a disease, but it is a process that occurs gradually as the consequence of cumulative changes; a process of the decrease of the body's resistance to face the stimulus from inside and outside the body. ${ }^{1}$ The main cause of the increase of BMI of the elderly is theimbalance between the energy released and the amount of food consumed. In short, it can be obtained through the consumption of energy-dense foods, high sugar and fat content and low physical activity due to sedentary from various types of profession, the changing of transportation models and the increase of urbanization. ${ }^{2}$

Physical activity that is done regularly and correctly can cause weight loss, cardiopulmonary function improvement, and minimize the LDL which has an impact on coronary heart prevention. ${ }^{3}$ Doing physical activity is highly recommended by the elderly as a mean to increase productivity in old days. Regular physical activity can also maintain the quality of life to stay healthy and fit and can increase the cardiorespiratory endurance. ${ }^{4}$ The elderly who continue to do physical activity can prevent the occurrence of mobility disabilities or functional disorders, while the elderly who are passive can increase the risk of health problems and the increase of body mass index in the elderly along with aging, the need for carbohydrates and fats which is generally lower inasmuch asthe decrease in basal metabolism.

The aims of this study is to know the correlation between body mass index and physical activity towards the cardiorespiratory endurance of the elderly, because good cardiorespiratory endurance increases physical durability and can decelerate exhaustion. ${ }^{6}$ Older people who have good cardiorespiratory endurance will have good productivity rates as well. This is to be known in the Banjar Alas Arum area for the monitoring of the fitness conditions of the elderly.

\section{METHODS}

\section{Research design}

This research is an analytical observational study using a cross sectional design where each subject was only observed once and the measurement of subject variables was carried out at the time of examination. This study took place in Banjar Alas Arum, Sesetan, Denpasar. This research was conducted in March-May 2021. 


\section{Population and Sample}

The population of this study was a reachable population. It was the elderly living in Banjar Alas Arum, Sesetan Village, South Denpasar who met the inclusion and exclusion criteria. The sampling of the inclusion criteria: (a) 60-74 years old, (b) signed informed consent aboutthe willingness to be a sample, (c) normal vital sign. The exclusion criteria: (a) History of shortness of breath and asthma, (b) Elderly who have cardiovascular disease and neurological diseases such as heart disease or stroke, (c) Fractures that do not allow them walking, (d) Smokers, if at the time of anamnesis, they are

Table 1. Characteristic of the respondents by gender

\begin{tabular}{ccc}
\hline Gender & Frequency (f) & Percentage (\%) \\
\hline Male & 30 & 62.5 \\
Female & 18 & 37.5 \\
Total & 48 & 100 \\
\hline
\end{tabular}

Table 2. Characteristic of the respondents by age

\begin{tabular}{lcc}
\hline Age Range & Frequency (f) & Percentage (\%) \\
\hline $60-64$ & 22 & 45.7 \\
$65-69$ & 19 & 39.7 \\
$70-74$ & 17 & 14.6 \\
Total & 48 & $100 \%$ \\
\hline
\end{tabular}

Table 3. Body mass index distribution of the respondents

\begin{tabular}{lcc}
\hline Body Mass Index & Frequency (f) & Percentage (\%) \\
\hline Underweight & 1 & 2.1 \\
Normal & 26 & 54.2 \\
Overweight & 15 & 31.3 \\
Obesity 1 & 6 & 12.5 \\
Total & 48 & 100 \\
\hline
\end{tabular}

Table 4. Physical activity levels of the respondents

\begin{tabular}{lcc}
\hline Physical Activities & Frequency (f) & Percentage (\%) \\
\hline Low & 14 & 29.2 \\
Moderate & 27 & 56.3 \\
High & 7 & 14.6 \\
Total & 48 & 100 \\
\hline
\end{tabular}

Table 5. Cardiorespiratory endurance levels of the respondents

\begin{tabular}{lcc}
\hline $\begin{array}{l}\text { Cardiorespiratory } \\
\text { Endurance }\end{array}$ & Frequency (f) & Percentage (\%) \\
\hline Poor & 3 & 6.3 \\
Bad & 11 & 22.9 \\
Moderate & 26 & 54.2 \\
Good & 4 & 8.3 \\
Very Good & 4 & 8.3 \\
Total & 48 & 100 \\
\hline
\end{tabular}

still smoking, (e) Taking drugs that can affect the cardiovascular system, (f) Sick on the day of the research. The elderly population of 70 people was selected according to the inclusion and exclusion criteria so that a sample of 48 people was obtained. The data collection was conducted the way the subject was collected in one house of 5-7 elderly and door to door with strict health protocols. Interviews were among the techniques used for collecting data and screening samples. Once a number of samples met the criteria of inclusion and exclusion, it resumes a vital sign measurement, a body mass index measurement, a physical activity with IPAQ (international physical activity questionnaire) and a cardiorespiratory endurance measurement using six minutes walking test.

\section{Data analysis}

The data of this study were analyzed using the SPSS v.26.0 for windows program with descriptive analysis including gender, age, body mass index, physical activity and cardiorespiratory endurance shown in the descriptive table and hypothesis testing using Somers' D analysis to analyze the correlation of independent variable (body mass index and physical activity) and dependent variable (cardiorespiratory endurance). The strength and the correlation (relationship) will have meaning if the relationship between the variables shows significant value $(\mathrm{p}<0.05)$.

\section{RESULTS}

\section{Characteristics of Respondents}

Table 1 shows that there are more male respondents than female respondents. There are 30 male respondents $(62.5 \%)$ and 18 female respondents (37.5\%). Table 2 shows that the age range of 60-64 years has the largest number of respondents with 22 respondents (45.7\%). The age range of $65-69$ years has a total of 19 respondents (39.7\%) and the age range of 70-74 years has a total of 7 respondents (14.6\%).

Table 3 shows that the most respondents was in the normal category, with 26 respondents (54.4\%), there was 1 respondent $(2.1 \%)$ in the underweight category. The overweight category was 15 respondents $(31.3 \%)$ and the obesity category 1 was 6 respondents $(12.5 \%)$.

Table 4 shows the most respondents is in the moderate category, with 27 respondents (56.3\%), in the low category there are 14 respondents (29.2\%) and in the high category, there are 7 respondents (14.6\%).

Table 5 shows that most respondents is in the moderate category, with 26 respondents (54.2\%), in 
Table 6. Cross table of body mass index towards cardiorespiratory endurance

\begin{tabular}{|c|c|c|c|c|c|c|c|c|c|c|c|c|c|}
\hline \multirow{3}{*}{ Body Mass Index } & \multicolumn{10}{|c|}{6 Minutes Walking Test } & \multirow{2}{*}{\multicolumn{2}{|c|}{ Total }} & \multirow{3}{*}{$p$} \\
\hline & \multicolumn{2}{|c|}{ Poor } & \multicolumn{2}{|c|}{ Bad } & \multicolumn{2}{|c|}{ Moderate } & \multicolumn{2}{|c|}{ Good } & \multicolumn{2}{|c|}{ Very Good } & & & \\
\hline & $f$ & $\%$ & $f$ & $\%$ & $\mathbf{f}$ & $\%$ & $\mathbf{f}$ & $\%$ & & $\%$ & $\mathbf{N}$ & $\%$ & \\
\hline Underweight & 0 & 0 & 0 & 0 & 1 & 2.1 & 0 & 0 & 0 & 0 & 1 & 2.1 & \\
\hline Normal & 2 & 4.2 & 0 & 0 & 17 & 35.4 & 4 & 8.3 & 3 & 6.3 & 26 & 54.2 & 0.000 \\
\hline Overweight & 0 & 0 & 6 & 12.5 & 8 & 16.7 & 0 & 0 & 1 & 2.1 & 15 & 31.3 & \\
\hline Obese 1 & 1 & 2.1 & 5 & 10.4 & 0 & 0 & 0 & 0 & 0 & 0 & 6 & 12.5 & \\
\hline Total & 3 & 6.3 & 11 & 22.9 & 26 & 54.2 & 4 & 8.3 & 4 & 8.3 & 48 & 100 & \\
\hline
\end{tabular}

Table 7. Cross table of physical activity towards cardiorespiratory endurance

\begin{tabular}{|c|c|c|c|c|c|c|c|c|c|c|c|c|c|}
\hline \multirow{3}{*}{$\begin{array}{l}\text { Physical } \\
\text { Activity }\end{array}$} & \multicolumn{10}{|c|}{6 Minutes Walking Test } & \multirow{2}{*}{\multicolumn{2}{|c|}{ Total }} & \multirow{3}{*}{$p$} \\
\hline & \multicolumn{2}{|c|}{ Poor } & \multicolumn{2}{|c|}{ Bad } & \multicolumn{2}{|c|}{ Moderate } & \multicolumn{2}{|c|}{ Good } & \multicolumn{2}{|c|}{ Very Good } & & & \\
\hline & $f$ & $\%$ & $f$ & $\%$ & $f$ & $\%$ & f & $\%$ & f & $\%$ & $\mathbf{N}$ & $\%$ & \\
\hline Low & 3 & 6.3 & 11 & 22.9 & 0 & 0 & 0 & 0 & 0 & 0 & 14 & 29.2 & \\
\hline Medium & 0 & 0 & 0 & 0 & 26 & 54.2 & 1 & 2.1 & 0 & 0 & 27 & 56.3 & 0.000 \\
\hline High & 0 & 0 & 0 & 0 & 0 & 0 & 3 & 6.3 & 4 & 8.3 & 7 & 14.6 & \\
\hline Total & 3 & 6.3 & 11 & 22.9 & 26 & 54.2 & 4 & 8.3 & 4 & 8.3 & 48 & 100 & \\
\hline
\end{tabular}

the very bad category there are 3 respondents (6.3\%). In the bad category, there were 11 respondents $(22.9 \%)$, good and very good categories respectively there are 4 respondents (8.3\%).

\section{Hypothesis testing}

Table 6 shows that respondents who have very good cardiorespiratory endurance have 2 categories of BMI. They are normal as many as 3 respondents $(6.3 \%)$ and overweight as many as 1 respondent (2.1\%). Respondents who have good cardiorespiratory endurance have 1 BMI category. They are normal as many as 4 respondents $(8.3 \%)$, respondents who have moderate cardiorespiratory endurance have 3 BMI categories. They are underweight as many as 1 respondent (2.1\%), normal as many as 17 respondents (35.4\%) and overweight as many as 8 respondents (16.7\%). Respondents who have poor cardiorespiratory endurance have 2 categories of BMI. They are overweight as many as 6 respondents (12.5\%) and obesity 1 as many as 5 respondents (10.4\%), very poor cardiorespiratory endurance has 2 categories of BMI. There are normal as many as 2 respondents (4.2\%) and obesity 1 as many as 1 respondent (2.1\%).

The results of Somers' D hypothesis test found that there was a significant correlation after obtaining the value of $p$ is 0.000 , it can be concluded ( $p<0.05$ ). It indicates that there is a significant correlation between body mass index and cardiorespiratory endurance in Banjar Alas Arum, Sesetan Village, South Denpasar.

Table 7 shows that the respondents who have very good cardiorespiratory endurance are in the high physical activity category, as many as 4 respondents (8.3\%). Respondents who have good cardiorespiratory endurance are found in 2 categories of physical activity. They are moderate as much as 1 respondent $(2.1 \%)$ and high as many as 3 respondents (6.3\%); the respondents who have moderate cardiorespiratory endurance are in the moderate physical activity category as many as 26 respondents (54.2\%);The respondents who have poor cardiorespiratory endurance are in the low physical activity category as many as 11 respondents (22.9\%) and very poor cardiorespiratory endurance are in the low physical activity category as many as 3 respondents $(6.3 \%)$.

The result of Somers' D hypothesis test shows that there was a significant relationship after the $p$-value of 0.000 , it can be concluded $(p<0.05)$ this indicates that there is a significant relationship between physical activity and cardiorespiratory endurance in Banjar Alas Arum, Desa Sesetan, South Denpasar.

\section{DISCUSSION}

\section{Characteristics of Respondents}

Age is one of the factors that can affect the elderly in carrying out some activities. Age can affect the quality and quantity of a person's physical activity related to daily physical activity. It is due to the increase of age will cause a decrease in physical capacity in the form of a decrease in muscle mass and strength, maximum heart rate, an increase in body fat or an increase in BMI along with the process of getting old so it will facilitate the accumulation of body fat. ${ }^{7}$ Old age is also one of the 
causes for an individual in having deterioration of cardiorespiratory endurance. It happens because if a person's age increases by a decade, $8-10 \%$ of their cardiorespiratory endurance will decrease if they are not regularly doing regular physical activity and maintaining a healthy diet. $^{8}$

The characteristics of respondents based on gender showed that there were more male respondents with 30 respondents, while female respondents were 18 respondents. Based on the data obtained, it shows that the female respondents experienced an increase in BMI both overweight and obesity and was low in physical activity. Male respondents have more muscle mass than female. Male respondents consume more calories than female even at rest.It causes female respondents gaining weight more easily than male even with the same calorie supply. In addition, at old age, female respondents experience a rapid decline in hormones due to menopause. ${ }^{9}$

Gender affects the level of fitness between men and women with maximum muscle strength accompanied by body composition, amount of hemoglobin, hormones, different lung capacities so that it greatly affects the level of fitness obtained according to Sharkey (2011). According to a study by the American Thoracic Society, the ability to walk during light physical activity of men is able to cover a distance of 580 meters while walking and normal women are only able to cover a distance of 500 meters. Several factors that affect it such as age, weight, height. body and others. ${ }^{10}$

\section{The Relationship Between BMI and Cardiorespiratory Endurance in the Elderly}

According to the analysis test results of this study, it can be seen that the elderly in Banjar Alas Arum, Sesetan Village, South Denpasar District on average have a normal BMI. This happens since the elderly in Banjar Alas Arum are still active in carrying out physical activities such as carrying out daily activities and the existence of gymnastics programs carried out in Banjar Alas Arum. This is also supported by active social interactions that make the elderly become more energetic and interact more with each other. Besides, environmental factor affects the lifestyle of the elderly. A healthy environment and support from the family to implement a healthy lifestyle are important for the elderly. An environment that forms discipline in carrying out a healthy lifestyle and maintaining the diet is important in forming a healthy lifestyle. ${ }^{4}$

Meanwhile, from the results of respondent characteristics by cardiorespiratory endurance, it can be concluded that the average elderly in Banjar Alas Arum, Sesetan Village, South Denpasar District has a dominantly moderate cardiorespiratory endurance. Moderate cardiorespiratory endurance was more commonly found in the normal BMI category. Cardiorespiratory endurance in the poor and very poor categories was more commonly found in BMI with overweight and obesity categories 1 . This is in line with the research conducted by Camellia (2018) which states that people with normal BMI have better cardiorespiratory endurance, specificallyfor the elderly. ${ }^{8}$

Someone who has a normal BMI will have less body fat levels than someone who has a BMI above normal. Excess body fat will interfere the process of breathing and blood flow in the elderly's body. The amount of fat especially for the elderly will affect the work of the respiratory muscles. As a result, it can cause changes in the muscles, cartilage, and joints of the thorax resulting in impaired respiratory movement and reduced thoracic stretching ability. If there is a change in the diaphragm muscle, the thoracic muscles become imbalance and cause distortion of the thoracic wall during respiration. Costal cartilage calcification results the decreased mobility of the ribs so that the expansion of the chest cavity and ventilation capacity decreases, resulting the decrease of cardiorespiratory endurance. ${ }^{11}$

The results of the Somers' D test conducted showed $p$ results of 0.000 where $(p<0.05)$, it can be concluded that there is a significant relationship between body mass index and cardiorespiratory endurance in the elderly. It is in line with the results of Andriani's study entitled the correlation between body mass index (BMI) and physical activity with maximum oxygen volume which says that there is a correlation between body mass index and maximum oxygen volume with sig ( $\mathrm{p}$ value) 0.016 which is smaller than the significant level value of $0.05(0.016<0.05) .{ }^{12}$

Another study that supports the results of this study is from Haslan entitled the correlation between body mass index and cardiorespiratory endurance, muscle strength and endurance which explains that the higher the body mass index, the lower the level of cardiorespiratory endurance with a significant relationship between the body mass index cardiorespiratory endurance $r=0.45$ and $\mathrm{p}=0.001(\mathrm{p}<0.05) .{ }^{13}$ This result is also supported by another study conducted by Nusdwinuringtyas which states that a good body mass index will affect cardiorespiratory endurance. ${ }^{14}$

Body mass index affects cardiovascular endurance directly and indirectly. This indirect cause links tothe combination of other factors. The internal factors consist of genetics, age, and gender while the external factors consist of a history of cardiovascular disease, smoking, food, physical 
activity and exercise habits. ${ }^{7}$ Obesity that occurs in a person can limit the flexibility in carrying out various activities. This will make obese people tend to be lazy to move so they will tend to have a sedentary lifestyle. This will lead to lower uptake of oxygen used and will lead to a decrease in cardiorespiratory endurance. ${ }^{15}$

The Relationship Between Physical Activity and Cardiorespiratory Endurance in the Elderly

According to the data of this study, it can be seen that many elderly people in Banjar Alas Arum, Sesetan Village, South Denpasar District have moderate physical activity categories. The medium category shows that the elderly in Banjar Alas Arum, Sesetan Village, South Denpasar District are still active in carrying out daily activities. Activities that are usually carried out by the elderly in Banjar Alas Arum such as household activities, walking, gymnastics, religious activities and so on. Someone who gets good fitness can be done with regular physical activity. Thus, to increase the ability to work on the cardiorespiratory system, a movement is needed through doing activities for people who have a very good cardiorespiratory work system are required to carry out regular physical activity. ${ }^{16}$

According to the respondent's characteristic data by cardiorespiratory endurance, it shows that moderate cardiorespiratory endurance mostly occurs in the moderate physical activity categorywhile good cardiovascular endurance mostly occurs in the high physical activity category. This is in line with research conducted by Budiyani which states that people who have a good level of physical activity will have good cardiorespiratory endurance with research results $\mathrm{p}=0.000$ which is smaller than the significant level of $0.05(0.000$ $<0.05){ }^{17}$

The results of the Somers' D test carried out showed $\mathrm{p}$ results of 0.000 where $(\mathrm{p}<0.05)$, which proved that there was a significant correlation between physical activity and cardiorespiratory endurance in the elderly where in the group that had good physical activity,the proportion of good cardiorespiratory endurance was obtained if it is compared with the low physical activity group with poor cardiorespiratory endurance.

The results of the study have proven that there is a significant correlation between physical activity and cardiorespiratory endurance in the elderly. This study is in line with the results of Sari's research entitledthecorrelation between physical activity and fitness (sixminutes walking test) of the elderly at the Permadi Dinoyo Health Center, Malang, Indonesia. $5 \%(0.000<0.05){ }^{18}$ This result is also supported by another study by Febriyanti which states that good physical activity will affect cardiorespiratory endurance with a p-value of 0.000 or $(\mathrm{p}<0.05){ }^{7}$

People who is used to do moderate to high physical activity need more energy such as oxygen in the body. It will increase so that there will be an improvement in breathing which causes an increase in cardiorespiratory endurance. This happens because the body's response to physical activity is the result of a coordinated response from organ systems, including the heart, lungs, blood vessels and muscles. The more muscle mass involved in physical activity, the greater the contribution of the muscle pump to the vein. This causes an increase in cardiac output which carries oxygen-rich blood throughout the body and makes cardiorespiratory endurance better. ${ }^{19}$

Moderate and high physical activity in the elderly in Banjar Alas Arum, Sesetan, South Denpasar such as walking for long durations and distances which causes differences in the level of physical activity in the low category due to the duration of the activity. The duration of physical activity is important to determine the level of physical activity category achieved by a person in the measurement. Physical activity that is carried out regularly and programmed for a longer time will give a better level of physical activity. ${ }^{16}$

The most active organ during physical activity is the skeletal muscle. ${ }^{20}$ As a result of skeletal muscle activity that is carried out regularly and measurably, it has a direct or indirect effect on the function of other body organs. Furthermore, it will improve the level of health and fitness. ${ }^{21}$ The increased level of health and fitness is caused by the function of the heart and circulation, the function of respiration, blood, the body's defense system, the increased performance of the neuro-muscular (nerve and muscle system) and spurring the development of the bones (skeleton). Theoretically, increasing physical activity by means of good, correct, regular physical exercisecan increase the degree of physical fitness (physical endurance). ${ }^{22}$

\section{CONCLUSION}

According to the results of the study it can be concluded that: 1 . There is a significant correlation between body mass index and cardiorespiratory endurance of the elderly in Banjar Alas Arum, Sesetan Village, South Denpasar District; 2. There is a significant correlation between physical activity and cardiorespiratory endurance of the elderly in Banjar Alas Arum, Sesetan Village, South Denpasar District.

It is recommended for the researcher who will conduct further research to examine wider sources 
to support the theory and select a larger sample of elderly people. It is also important to provide appropriate age limits and better measurement for future research.

\section{CONFLICT OF INTEREST}

There is no conflict of interest in this study.

\section{FUNDING}

None.

\section{AUTHORS CONTRIBUTIONS}

IKDWD conceived the study design, data collection, analyzed the data, and writing the manuscript; IPPJ and IMDP conducted data analysis and writing the manuscript.

\section{REFERENCES}

1. Wahyudi N. Keperawatan Gerontik dan geriatrik. Jakarta: EGC. 2008.

2. Organization WH. Overweight and obesity. 2020.

3. Dinata WW. Menurunkan Tekanan Darah Pada Lansiamelalui Senam Yoga. JORPRES (Jurnal Olahraga Prestasi). 2015;11(2).

4. Kamaruddin I. Indeks Massa Tubuh (IMT) Terhadap Daya Tahan Kardiovaskuler. SPORTIVE: Journal Of Physical Education, Sport and Recreation. 2020;3(2):117-22.

5. Fatmah D. Gizi usia lanjut. Jakarta: Erlangga. 2010:16-33.

6. Brian SJ. Kebugaran dan kesehatan. Jakarta: PT RajaGrafindo Persada. 2011.

7. Febriyanti NK, Adiputra IN, Sutadarma IWG. Hubungan indeks massa tubuh dan aktivitas fisik terhadap daya tahan kardiovaskular pada mahasiswa Fakultas Kedokteran Universitas Udayana. Erepo Unud. 2015;831:1-14.

8. Nurjannah C, Rahfiludin MZ, Kartini A. Hubungan Asupan Makronutrien, Indeks Massa Tubuh (Imt) Dan Aktivitas Fisik Dengan Kesegaran Jasmani Pada Lansia (Studi di Posyandu Lansia Bumi Asri RW IV Kelurahan Sambiroto, Kecamatan Tembalang, Semarang Tahun 2018). Jurnal Kesehatan Masyarakat (e-Journal). 2018;6(5):31725.

9. Dixon AE, Holguin F, Sood A, Salome CM, Pratley RE, Beuther DA, et al. An official American Thoracic Society Workshop report: obesity and asthma. Proc Am Thorac Soc. 2010;7(5):325-35.
10. Harikatang AD, Rampengan SH, Jim EL. Hubungan antara jarak tempuh tes jalan 6 menit dan fraksi ejeksi pada pasien gagal jantung kronik terhadap kejadian kardiovaskular. e-CliniC. 2016;4(1).

11. Utomo B, Pudjiastuti S. Fisioterapi pada lansia. Jakarta: Buku Kedokteran EGC. 2003.

12. Andriani R, Herawati I, Fis S. Hubungan Antara Indeks Massa Tubuh Dan Aktivitas Fisik Dengan Volume Oksigen Maksimum: Universitas Muhammadiyah Surakarta; 2016.

13. Lubis HM, Sulastri D, Afriwardi A. Hubungan Indeks Massa Tubuh dengan Ketahanan Kardiorespirasi, Kekuatan dan Ketahanan Otot dan Fleksibilitas pada Mahasiswa Laki-Laki Jurusan Pendidikan Dokter Universitas Andalas Angkatan 2013. Jurnal Kesehatan Andalas. 2015;4(1).

14. Nusdwinuringtyas N. Kesahihan dan Keandalan Uji Jalan 6 Menit pada Lintasan 15 Meter (Validity and Reability of 6 Minutes Walk Test on the 15 Meters Track). Jurnal Media Penelitian dan Pengembangan Kesehatan. 2018.

15. So W-Y, Choi D-H. Differences in physical fitness and cardiovascular function depend on BMI in Korean men. J Sports Sci Med. 2010;9(2):239.

16. Suharjana S. Profil Kebugaran Fisik Pelajar Slta di Kabupaten Kulon Progo Daerah Istimewa Yogyakarta. Jurnal Cakrawala Pendidikan. 2008;3(3).

17. Budi Yani Y, Herawati I, Fis S. Hubungan Aktivitas Fisik dengan Daya Tahan Jantung dan Fleksibilitas Punggung pada Lansia di Posyandu Lansia Dong Biru Semarang: Universitas Muhammadiyah Surakarta; 2017.

18. Sari NA. Hubungan Antara Aktivitas Fisik Dengan Kebugaran (Six Minute Walking Test) Pada Lansia Di Posyandu Lansia Permadi Dinoyo Kota Malang: University of Muhammadiyah Malang; 2018.

19. Ariyanto A, Cinta NP, Utami DN. Aktivitas Fisik Terhadap Kualitas Hidup Pada Lansia. Jurnal Kesehatan Al-Irsyad. 2020;13(2):145-51.

20. Wardani NEJ, Roosita K. Aktivitas fisik, asupan energi, dan produktivitas kerja pria dewasa: studi kasus di perkebunan teh malabar PTPN VIII Bandung, Jawa Barat. Jurnal Gizi dan Pangan. 2008;3(2):71-8.

21. Widodo BS, Kusnanik NW. Tingkat Kesegaran Jasmani pada Siswa SMP Negeri 2 Krembung dan SMP Negeri 2 Sidoarjo. Jurnal Prestasi Olahraga. 2013;1(1).

22. Jaihar S, Dachlan D, Yustini. Analisis status gizi dan aktivitas fisik dengan ketahanan fisik siswa di Sekolah Polisi Negara (SPN) Batua Makassar, Sulawesi Selatan. Fakultas Kesehatan Masyarakat Universitas Hasanuddin, Makassar; 2013.

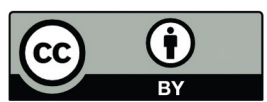

This work is licensed under a Creative Commons Attribution 